TP Periodica Polytechnica

22(1), pp. 29-35, 2014

DOI:10.3311/PPso.7426

http://www.pp.bme.hu/so/article/view/7426

Creative Commons Attribution (i)

RESEARCH ARTICLE

\section{Investment in the Human Capital as the Source of Economic Growth}

Alžbeta Kucharčíková

RECEIVED 08 MAY 2013 ACCEPTED AFTER REVISION 09 October 2013

\begin{abstract}
The aim of this text is to show the necessity of investment in human capital. The article discusses the importance of human capital as a source of economic growth and its role for the achievement of extensive and intensive economic growth. The article shortly describes the problem of costs and benefits of investment in human capital. The text answers the questions who and why ought to invest, which are determinants of investment in human capital and how the human capital contributes to the economic growth and improving welfare of the population.
\end{abstract}

\section{Keywords}

economic growth $\cdot$ human capital $\cdot$ investment in human capital $\cdot$ education

\section{Alžbeta Kucharčíková}

Department of Macro and Microeconomics,

Faculty of Management Science and Informatics, University of Žilina, Univerzitná 8215/1, 01026 Žilina, Slovak Republic

email: Alzbeta.Kucharcikova@fri.uniza.sk

\section{Introduction}

We live in a time of rapid introduction of modern techniques and technologies into the production. Changes in economic development today and in future will require increased investment in human capital, especially in education at all its levels. Therefore it is important to pay attention to education and lifelong learning of citizens. It is the best investment that activates the human and the whole nation. Economists of past and present economic schools emphasize just that. We talk about the need for investment in human capital, which in economic terms is a source of intensive and extensive economic growth.

\section{The Sources of the Economic Growth}

Economic growth is one of the main objectives of the economic policies of current governments. This is achieved by extensive or intensive use of production factors. Extensive economic growth is the result of quantity increasing of used production factors. Basic factors of production are land, labour and capital (physical and human).

The land as production factor includes all components of the natural environment. This source is often used for marking natural sources, but some economists connected this factor with capital. It was the decisive factor of production to achieve growth, in the period before the Industrial Revolution. The most of the workforce is employed in agriculture in many developing countries, currently. If economic growth rate is too high, then there is the depletion of natural sources. For this reason, we are talking about sustainable growth not leads leading to their depletion.

The labour is another source of economic growth, which is achieved through the increase of labour force. It is influenced by demographic trends, amount of labour force, scientific and technical progress level, the social division of labour and labour productivity in various sectors. Present modern technologies require fully skilled workers for the operation and maintenance. Therefore it is necessary to increase the labour force qualification.

The capital is a rare source. The term capital is very wide and capital as a source of economic growth includes buildings, machinery, equipment, technology. A prerequisite of capital 
accumulation is the creation of savings. Capital accumulation changes the ratio between production factors. At present, capital accumulation is increasingly directed to education and research. The economists demerged capital on physical and human capital in the 80 -ies of the $20^{\text {th }}$ century.

The human capital includes the natural ability, innate and acquired skills, knowledge, experience, talent, inventiveness. All these characteristics are components of the human capital. The essence of creation, increasing the value and effectiveness of human capital, is spending money now but expected benefits will flow in future. Forms of increasing the value of human capital are expenditure oriented for example to health, safety, science, research and education [14].

\section{Definitions of the Human Capital}

A lot of economists defined the human capital. They were representatives of the Chicago school in the 60s of the 20th century. Attention of Chicago economists also was focused on building human capital theory, which was a major contribution to theoretical research in education. Their theory of human capital has become a "decoration" Chicago School [26].

The leader of this school was Th. Schultz, who in 1981 wrote: "Take into account the innate and acquired skills. Those are important and may invest to expand, will form the human capital. "[18]

The most important author and promoter of human capital theory is G. Becker. In his book Human Capital in 1964 developed a theoretical basis for deciding on investment in human capital [2].
N. Bontis, N. C. Dragonetti, K. Jacobsen a G. Roos [4] defined the human capital as the human factor in the organization; the combined intelligence, skills and expertise that gives the organization its distinctive character. The human elements of the organization are those that are capable of learning, changing, innovating and providing the creative thrust which if properly motivated can ensure the long-run survival of the organization.

Davenport [7] says that people possess innate abilities, behaviours and personal energy and these elements make up the human capital they bring to their work.

M. Armstrong [1] defines the human capital as knowledge and skills, which individuals create, maintain and use. New theories of economic growth characterized the human capital as the sum of the individual congenital and acquired skills, knowledge, experiences of individuals.

OECD defines human capital as knowledge, skills, abilities and other characteristics that are relevant for economic activity [21].

\section{Approaches to Understanding of the HumanCapital}

After comparing different views on the definition and understanding of the human capital, we can conclude that, in principle there is microeconomic and macroeconomic approach. In microeconomic view, there are two basic approaches. In terms of business economics is human capital considered as production factor. Managerial view sees human capital as a business resource or asset which forms part of the market value of the company. The macroeconomic approach sees human capital as

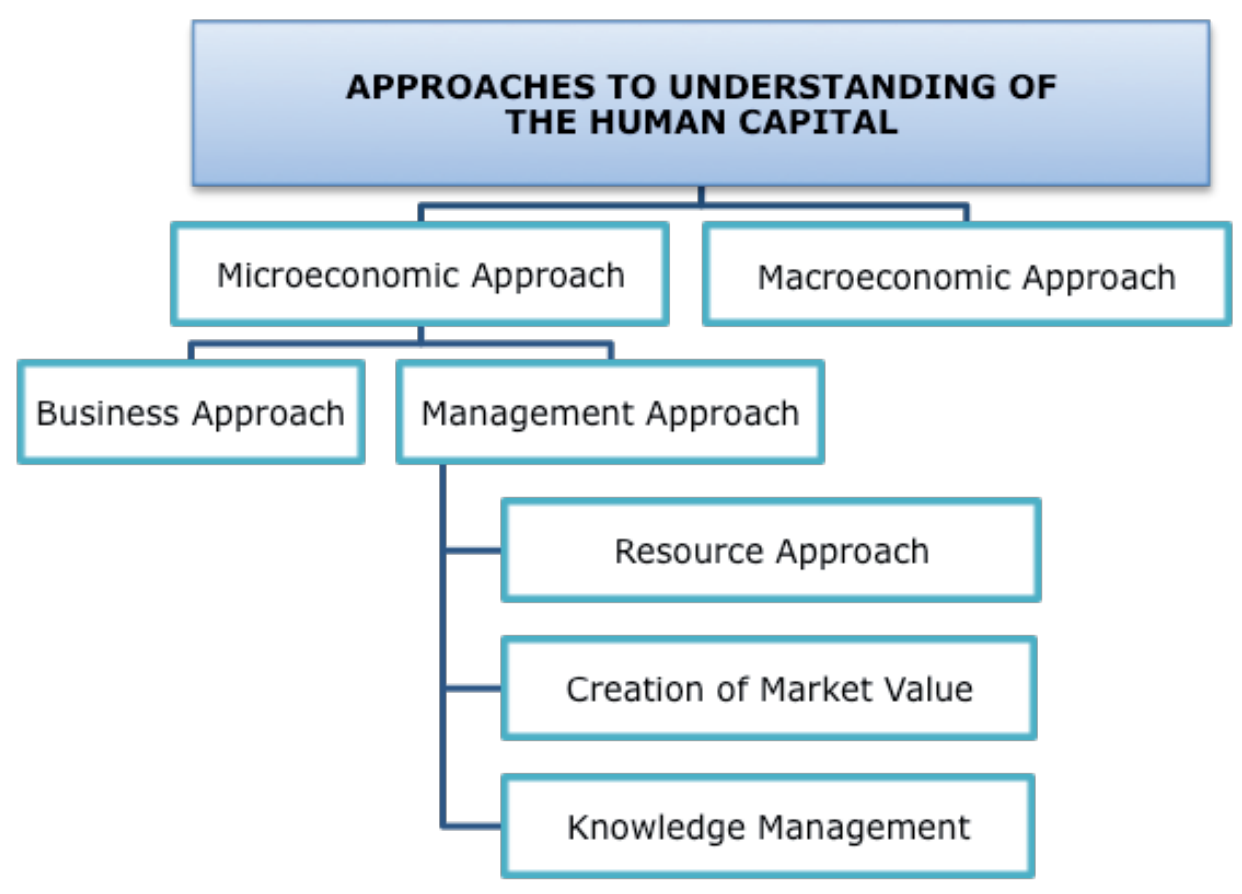

Fig. 1. Approaches to Understanding of the Human Capital (Source: own design) 
one of the production factors, respectively sources of economic growth [13].

\section{Business Approach}

In terms of business economics human capital can be considered as one of the business production factors, which are material, property and human labour. All of which introduced costs for the company. But human capital does not work directly, but this is only one aspect of the human labour - a qualitative aspect.

\section{Management Approach}

Management approach considers human capital as intangible company asset, which is a part of the intellectual capital and they influences the market value of the company. The process of enterprise value creation is different described by different authors.

\section{Resource Approach}

Koubek [11] writes about business resources that are material (machinery, equipment, energy), financial, information and human. Human resources have the decisive role in business management, economy, personnel work. Human resources are considered as holders of human capital. Employees are not just another resources, so that personal activities must be guided by a management philosophy which seeks to involve them [16].

Human capital represents the factor which gives a specific character to every organization. People are that element in the company which is able to learn, to innovate, to stimulate and to make the changes as well as to think a creatively. This all is important for long-term successful operation of a company on the market [24].

\section{Creation of Market Value according to Scandia}

New and dynamically changing market environment forces the companies to maintain its competitiveness. Companies search new ways as to create the market value, as to provide a exeptional services for their customers [12].

Organizations use different approaches for accumulating and utilizing their knowledge, and that these approaches present themselves as different aspects of intellectual capital, i.e., human, organizational, and social capital [7]. The concept of intellectual capital is based on the belief, that the main resources for building competitive advantage are intangible in nature. Edvinsson and Malone [10] used for the first time the word, "Intellectual Capital", instead of the accounting term "Intangible Assets".

Scandia is the first large company to have made a truly coherent effort at measuring human assets. According to Scandia's model, the hidden factors of human and structural capital comprise the intellectual capital when added together [10].

Intellectual capital is the sum of human and structural capital. There are experience, organizational technology, customer relationships and professional skills. Human capital is combined knowledge, skill, innovativeness and ability of the company's individual employees to meet the task at hand. Human capital cannot be owned by the company. Structural capital is the hardware, software, databases, organizational structure, patents, trademarks, and everything else of organizational capability that supports those employees' productivity - in other words, everything that gets left behind at the office when employees go home. Structural capital also provides customer capital, the relationships developed with key customers [4].

\section{Creation of Market Value according to Sveiby}

Sveiby [19] called intellectual capital as an intangible asset. He proposes a conceptual framework based on three families of intangible assets: external structure (brands, customer and supplier relations), internal structure (the organization management, legal structure, manual systems, attitudes, R\&D, software) and individual competence (education, experience, skills). The concept of individual competence corresponds to the concept of human capital, which is given to this article and which is frequently used in theory. Sveiby [20] proposes a method for the measurement of intangible assets (other authors refer to their intellectual capital) because intangible assets contribute to the increase in value. In traditional accounting, these assets are regarded as costs. He argues that both non-financial measures to measure intangible assets and financial measures to measure visible equity can be jointly used to provide a complete indication of financial success and shareholder value.

M. Armstrong [1] explained the concept of human, intellectual, social and organizational capital. Individuals generate, retain and use knowledge and skill (human capital) and create the intellectual capital. Their knowledge is enhanced by the interactions between them (social capital) and it generates the institutionalized knowledge possessed by an organization (organizational capital).

\section{Knowledge Management}

P. Drucker [9] was the first who enriched the management that there is a new kind of capital, and called it to the knowledge capital. He predicted that, while money capital will subside, knowledge capital will promote. Knowledge or human capital is more and more considered the most valuable capital of the company. Human capital is not the same for everyone. Holder of knowledge capital can be creative and skilled worker or professional manager. The world is fast moving from a production-based economy to a knowledge-based one [8].

Nonaka and Takeuchi [17] said, that knowledge management requires a commitment to "create new, task-related knowledge, disseminate it throughout the organization and embody it in products, services and systems". At the organizational level, knowledge is generated from internal operations or from outside sources communicating with the corporate structure. 
Davenport and Prusak [7] defined knowledge as sum of experience, values, contextual information, and expert insight that provides a framework for evaluating and incorporating new experiences and information. Knowledge management deals with the creation, acquisition, integration, distribution, and application of knowledge to improve the operation effectiveness and competitive advantage of an organization.

\section{Macroeconomic Approach to the Human Capital}

By macroeconomic approach, the human capital is one of the sources of extensive economic growth. Education, as form of investment in human capital, belongs to resources of intensive economic growth.

\section{An Intensive Economic Growth}

Intensive economic growth is caused by the increase in production per unit of input. This type of economic growth is influenced by the quality, efficiency and manner of combining production factors. The intensive growth sources include the technical progress and enhancement of the total factors productivity.

Technological progress is reflected by developing new and better capital goods and technologies. It is supported by large innovations. The application of technical progress requires the introduction of more modern and better management methods, work organization, career development, appropriate education level of managers and workers who work with new technologies. Technological progress requires a rising level of education and research. But particularly highly skilled and educated people contribute to technical progress, through innovations. In this way, technological progress leads to increasing productivity and efficiency of all production factors.

Aggregate productivity growth occurs, when the product increases by effective use of inputs, with the same quantity of production factors. This is reflected in: labour productivity - increase in volume of the real product that created an employee; efficiency of capital growth - it is reflected in a higher volume of real product, which falls on the capital employed; decline in material and energy intensity of production - reducing the quantity of material and energy needed to produce a unit of product.

Determinants of aggregate productivity factors are: the level of work organization, technology, technical support, the level of education, motivation of employees to increase their performance, and also the natural and soil conditions. In the current period, which is characterized by rapid and extensive introduction of technical innovations, education is the most important factor. It contributes to the technological progress, factors productivity growth, increasing value of the human capital and overall economic growth. New knowledge and skills must be adapted to current needs and possibilities of concrete firms and economies in an innovative and creative way. Economists Th. Schultz and E. Denison emphasized investments in education contribute to economic growth and its accelerating, already in the 50 -ies and 60 -ies of the $20^{\text {th }}$ century [14].

\section{The Combination of Growth Sources from the Aspect of Society Historical Development}

Structural changes caused that at various stages of society development the importance and the combination of key growth sources (production factors) are varied. If we look at the use of production factors in terms of historical development of society, then in the long term agrarian society considered the land as a key factor in combination with heavy physical labour.

Several millennia-long primacy of land was terminated by the industrial revolution in England in 1760 and this was the start of an industrial society. The capital - again in combination with the physical labour - was the most important production factor in this type of society. Industrial society included the development of mechanization, automation, introduction of new technologies and techniques leading to higher labour productivity and to economization the labour force.

Industrial society was replaced by the information society (or post-industrial, knowledge society) in the U.S.A. in the 50 -ies years of the $20^{\text {th }}$ century. As a result of globalization and strong competition fight, important innovations, massive use of information and communication technologies (ICT) are very important in this type of human society. Introduction of robotics increases the importance of psychical labour to the detriment of physical labour. In information society - the managers in enterprises can create their own specific database of specific contacts, because the networks make it possible to locate them directly (according to profiles, school attendance, capabilities, experiences, published works), or indirectly, through recommendations (friends, colleagues, supervisors, trainers). If the HR manager cannot find a searched specialist, the networks offer the possibility to write a blog (website) [22]. The human capital began to be regarded as an important source of economic growth.

The basic prerequisite for the successful building an information society is a high level of education in economic subjects. Education is therefore crucial and from the perspective of ICT it has two levels. It is education in computer science. Here the education is the subject and object of science, too and the education is designed to prepare professionals in the field of informatics. The second plane is about education in other areas using the methods and means of informatics, when we talk about informatization of education [15].

There are extensive and intensive growth sources. Human capital is an important source of extensive and intensive growth, too. "Economic growth is closely linked to the speed with which world get ready to use new technologies, especially in the information and communication field. Human capital is relatively young production factor. Because it is closely related 
to production factors of labour and has features in common with the labour, analysis and research work it is often not explicitly mentioned." [23]

The new modern theories of economic growth $(80-90$ years of 20th century) had begun to take the human capital as one of the main factors of economic growth. "New growth theory is based on the assumption that the production function is not affected only by labour (as a physical and psychical activity) and capital, but also by education, improving the quality of labour and capital, better infrastructure, which are unaffected by exogenous but endogenous. This means that the growth of education and upgrading skills operate as a multiplier, which makes for faster economic growth." [26] These economic theories know physical and human capital. Physical capital is the machines, equipment and technologies. Human capital is the sum of inborn or obtained knowledge, competencies, skills and experiences of the individuals.

\section{Investment in the Human Capital}

Investment in human capital is oriented to development of knowledge and skills of workers. Economic subjects invest to the human capital when they expect future benefits. Investment in human capital are realised as investment in education and training.

Education is the process of purposeful mediation, creating an active acquisition of knowledge, practical experience, creating interest and attitudes. Education and training is currently considered one of the major factors enable economic recovery economic growth and development, thus growth welfare for individuals and international competitiveness.

Intensive technical development brings new discoveries, new and rapidly changing technology, a new focus on the technical level, quality of services based primarily on the customer

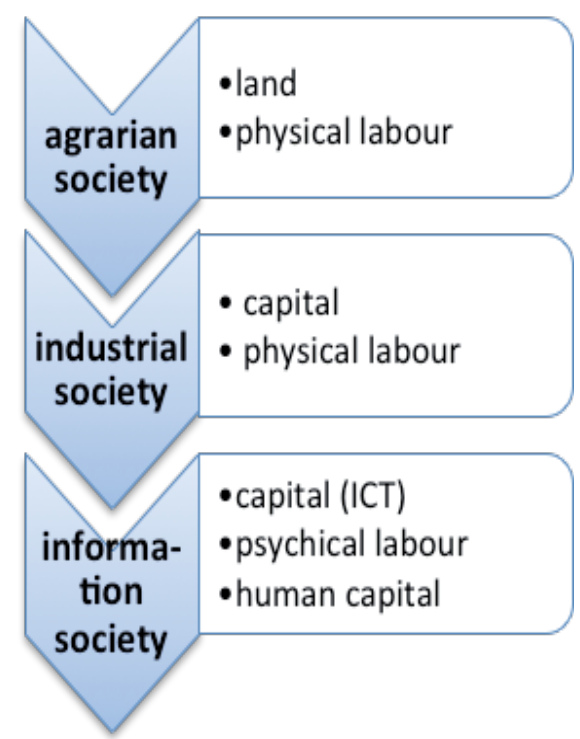

Fig. 2. Combination of Key Growth Sources from the Aspect of Historical Development of Human Society (Source: own design) and his needs. All this requires constant improvement and expansion of knowledge, skills, formation of professional skills of employees.

We know various types of education. Formal education is realized in schools. It is institutionalized education which leads up to obtain a certain degree of education. It provides primary, secondary and tertiary education. Informal adult education is realized outside the school education system. It is aimed at a particular group of people and it is organized by different institutions (firms, clubs, foundations, adult education institutions). This may be general (exchangeable) or special (unalterable) education. General education is focused on the ability to obtain information, to understand and analyze it. Special education is aimed at creating a special qualification for a special type of work.

Expenditure on education oriented to achieve, sustain and enhance the range of skills and abilities of people are considered to be investment, because they contribute to output size in the future. This investment represents a form of increasing the value of human capital as one of the production factors. Investment allows the creation of a strong and flexible labour force being able to respond flexibly and rapidly to changes, which are associated with the globalization process and the transition to an information society.

The determinants of investment in human capital are the wage and age of individual, greatness of firms, nature of industry, population growth, economic standard, type of educational institution and financial position of the economic subjects.

The economic subjects invest in the human capital (or in education), when the benefits exceed the costs of education activities. But the problem is measuring the benefits, therefore value of some benefits is appraised. There are some costs and benefits of investment in education. Costs: direct costs - buildings, books, study materials, wages for teachers, fare, accommodation; opportunity costs - lost income of employees and students. Benefits: individual benefits - growth of real wages, advantage position on the labour market, pleasure of education. Firm benefits - growth of production, services, quality, labour productivity; decrease in costs; other innovations, high quality relationship with customers, growth of competitive ability on market, shorter processing times, reduced overtime, improve skill levels. Society benefits - growth of population knowledge level, efficiency of economy, development regions, economic growth, increasing the living standard.

The market participants, which obtain the benefits or effects, ought to invest in education, training or human capital. The individuals invest with expecting of wage growth. According to human capital theory the rate of return investment decreases with growth of person age. On account of that people often invest on start of their work career [2].

When the firms invest in the general human capital (utilised on whatever workplace), it is a risk of skilled worker's 
departure to the other firm. Therefore is motivation of employees very important. For the firms is more advantage to invest in the specific human capital (specific skills and knowledge utilised only in the concrete workplace). This is a way as to secure the employment stability, too.

Development of human capital is contribution for the whole economy. The skilled and trained people contribute to growth of cultural and living standard. These effects are called the external economies. On account of that government ought to invest in human capital, too.

A lot of market participants (individuals, firms, government) understand the necessity and importance of investment in education and training (human capital), but the problem is shortage of finance. Figure 3 shows the link between technological changes and investment in the human capital and shows some benefits of education of the economic subjects.

\section{Conclusion}

The firms and the economies work in new global economic area. There are realised extensive industry changes, at present. "Innovations are changing the style of working life, emphasize the importance of education, creativity, communication and cooperation." [6]

The competence of efficiency utility of knowledge and skills are the basic of the new economy. Firms and society need high competent workers. Therefore growth of human capital quality is very important. There are a lot of definitions and approaches to the human capital and the topic of human capital is very extensive.

There are some benefits of investment in education, for example growth of the production, services, quality, labour productivity, decrease in costs, other innovations, high quality relationship with customers, growth of the competitive ability on market. On the other side, investment in the human capital contributes to intensive economic growth.

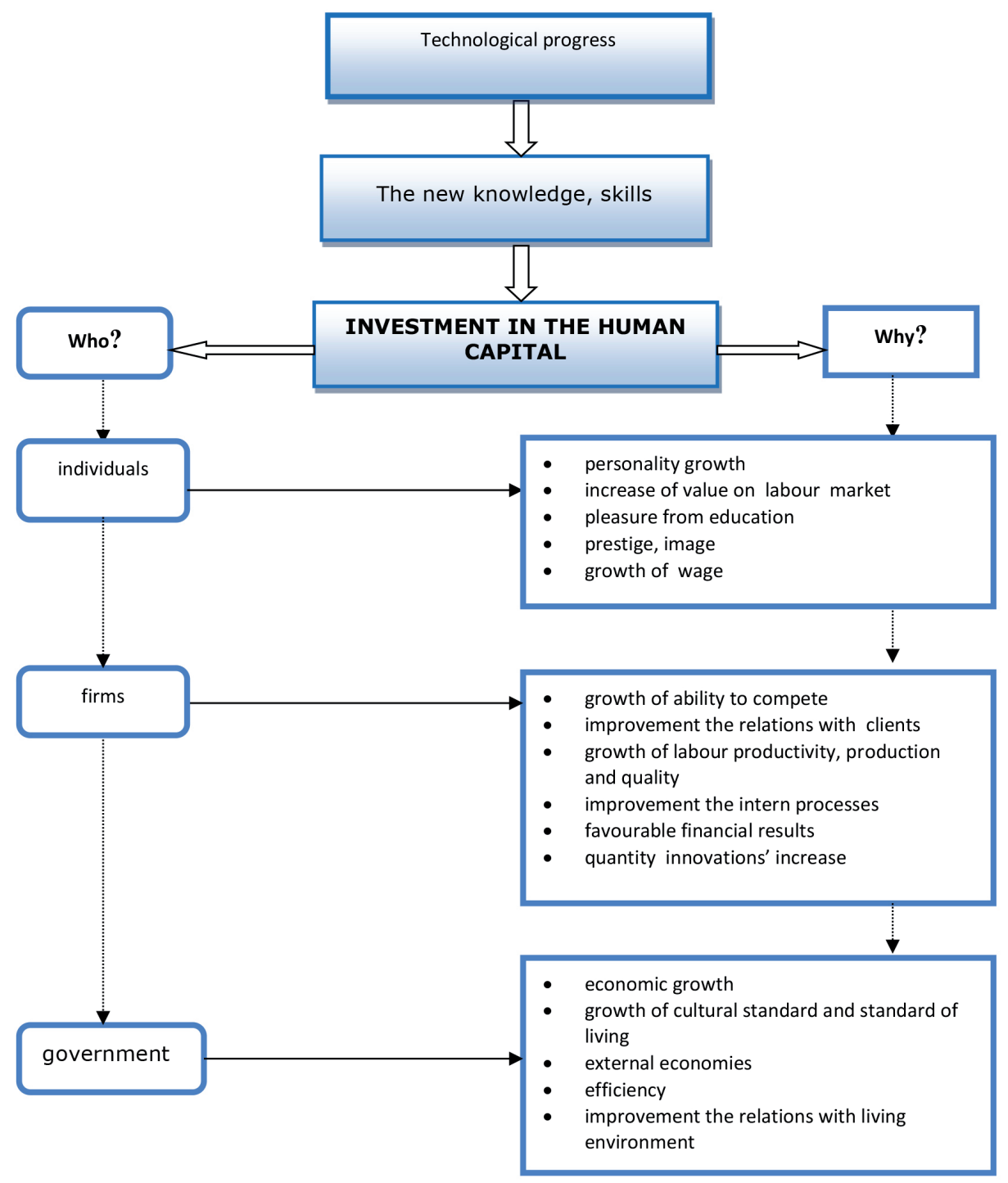

Fig. 3. Who and Why Ought to Invest in the Human Capital (Source: own design) 


\section{Acknowledgement}

This article is a result and it has been supported by Scientific grant VEGA No 1/0421/13.

\section{References}

1 Armstrong M., A Handbook of Human Resource Management Practice. London (2006).

2 Becker G. S., Human Capital-A Theoretical and Empirical Analysis, with Special Reference to Education. $3^{\text {rd }}$ ed., The University of Chicago Press, Chicago, London (1993).

3 Benedek A., Molnár G., Development of Teacher Competencies in a New Learning Environment in Higher Education, ICCGI 2012: The Seventh International Multi-Conference on Computing in the Global Information Technology, 95-99 (2012).

4 Bontis N., Assessing knowledge assets: a review of the models used to measure intellectual capital. IJMR (2001).

5 Bontis N., Dragonetti N. C., Jacobsen K., Roos G., The knowledge Toolbox: a review of tools available to measure and manage intangible resources. European Management Journal, 17 (4), 391-402 (1999) DOI: 10.1016/S0263-2373(99)00019-5

6 Chodasová Z., Innovations in Corporate Governance. International science conference Market Economic Knowledge for Practice, Palacky University in Olomouc 11.9.2008, Czech Republic, 192-195 (2008).

7 Davenport T. H., Prusak L., Working Knowledge. HBS Press, Cambridge (1998).

8 Drucker P. F., Knowledge-worker productivity: the biggest challenge. California Management Review, 41 (2), 79-94 (1999). DOI: $10.1108 / 14637150410518301$

9 Drucker P. F., Postcapitalist Society. Harper Collins Publishers, New York (1993).

10 Edvinsson L., Malone M. S., Intellectual Capital: Realizing Your Company's True Value, by Finding its Hidden Roots. Harper Collins Publishers, New York (1997).

11 Koubek J., Human Resource Management. Management Press, Praha (2007).

12 Kožená M., Globalization and its impact on business competitiveness. International science conference Globalization and its Socio-Economic Consequences, The Faculty of Operation and Economics of Transport and Communications, University of Žilina, Rajecké Teplice 4.-6.10.2010, 266-269 (2010). 